\title{
Hubungan Kesiapan Keluarga dengan Kondisi Demensia Lansia
}

\author{
S. Theresia Handayani Sembiring ${ }^{1}$, Elizabeth Ari Setyarini ${ }^{2 *}$ \\ ${ }^{1,2}$ Sekolah Tinggi Ilmu Kesehatan Santo Borromeus, Bandung, Indonesia \\ *Email korespondensi: elizabeth.rini@yahoo.com
}

\section{ARTICLE INFO \\ HOW TO CITED: \\ Sembiring, S. T. H., and Se- tyarini, E. A. (2019). Hub- ungan Kesiapan Keluarga dengan Kondisi Demensia Lansia. Jurnal Pendidikan Keperawatan Indonesia 5(1), p. $42-50$}

DOI:

10.17509/jpki.v5i1.15722

\section{ARTICLE HISTORY:}

Accepted

April 15, 2019

Revised

May 02, 2019

Published

June 26, 2019

\begin{abstract}
A B S T R A K
Indonesia adalah negara yang termasuk era penduduk berstruktur lansia karena jumlah penduduk yang berusia 60 tahun keatas sekitar 7,18\%. Meningkatnya populasi lanjut usia ini menimbulkan berbagai perubahan yang berdampak pada masalah kesehatan, salah satunya adalah fungsi kognitif yaitu demensia. Penurunan fungsi kognitif ini menyebabkan lansia membutuhkan bantuan orang lain dalam aktivitasnya. Keluarga memiliki peran yang sangat penting dalam perawatan lansia demensia yang tinggal di rumah. Tujuan penelitian ini mengidentifikasi hubungan kesiapan keluarga dengan kondisi demensia lansia di Posbindu. Penelitian dengan metode kuantitatif dengan desain penelitian cross sectional dan total sampling yangdilaksanakan pada Bulan Mei - Juni 2017. Hasil uji Chi-Square diperoleh $p$-value $=0,896$, hal ini berarti bahwa Ha ditolak sehingga tidak ada hubungan kesiapan keluarga dengan kondisi demensia lansia. Kesimpulan penelitian tidak ada hubungan kesiapan keluarga dengan kondisi demensia lansia di Posbindu RW 06 Cimareme. Rekomendasi penelitian adalah pentingnya kesiapan dan pendampingan keluarga dalam memberikan rasa nyaman dan aman pada lansia dalam keluarga.
\end{abstract}

Kata kunci: demensia, kesiapan keluarga, lanjut usia

\section{$A B S T R A C T$}

Indonesia is a country which includes an era of Aging Structured Population because the population aged 60 years and above is around $7.18 \%$. The increase in the elderly population raises various changes that have an impact on health problems, one of which is cognitive function, namely dementia. This decline in cognitive function causes the elderly to need help from others in their activities. Families have a crucial role in the care of elderly dementia who live at home. The purpose of this study was to identify the relations between family readiness with dementia conditions of the elderly at Subdistrict Center Health Care. The research with a quantitative method with crosssectional and total sampling design was carried out from May to June 2017. The Chi-Square test results obtained $p$-value $=0.896$, this means that Ha was rejected, so there were no relations between the relations between family readiness with dementia conditions of the elderly. The study concluded that there were no relations between the relations between family readiness with dementia conditions of elderly at Subdistrict Center Health Care. Research 
providing a sense of comfort and safety to the elderly in the family.

Keywords: dementia, elderly, family preparedness

\section{PENDAHULUAN}

Indonesia adalah negara yang termasuk era penduduk berstruktur lansia (Aging Structured Population) karena jumlah penduduk yang berusia 60 tahun keatas sekitar 7,18\%. Meningkatnya populasi lanjut usia ini menimbulkan berbagai perubahan yang berdampak pada masalah kesehatan, salah satunya adalah fungsi kognitif yang mengalami penurunan. Penurunan fungsi kognitif ini disebabkan berkurangnya jumlah sel saraf (neuron) dan kematian sel secara terus menerus, berkurangnya aktivitas otak dan asupan nutrisi yang kurang (Mujahidullah, 2012).

Secara garis besar, prevalensi lansia yang mengalami penurunan fungsi kognitif di Amerika Serikat mencapai $19,2 \%$ pada lansia yang berusia antara 65-74 tahun dan $27,6 \%$ pada lansia yang berusia $75-84$ tahun serta $38 \%$ pada lansia yang berusia di atas 85 tahun (Administration on Aging, 2004). Wilayah Asia, misalnya di Cina dan Taiwan, prevalensi lansia yang mengalami kemunduran fungsi kognitif berkisar antara 9,9\%-45,7\% pada lansia yang berusia antara 60-108 tahun (Yen, 2010). Indonesia sendiri, belum terdapat data mengenai prevalensi penurunan kognitif pada lansia secara keseluruhan akan tetapi penelitian mengenai gambaran gangguan fungsi kognitif yang dialami lansia di Indonesia telah banyak dilakukan.

Penurunan fungsi kognitif ini menyebabkan lansia membutuhkan bantuan orang lain dalam aktivitasnya. Penelitian Maryam, Rosidawati, Riasmini dan Suryati (2012) mendapatkan hasil bahwa $52,2 \%$ keluarga mengalami beban tinggi dalam merawat lansia. Beban merawat lansia tersebut merupakan respon multidimensi terhadap stressor fisik, psikologis, sosial, dan finansial. Penurunan fungsi kognitif ini akan terus berkembang seiring bertambahnya usia lansia dan bila tidak tertangani dengan baik, dapat menyebabkan kemunduran fungsi kognitif yang sedemikian beratnya sehingga mengganggu ak- tivitas hidup sehari-hari dan aktivitas sosial. Hal inilah yang menyebabkan lansia mengalami ketergantungan dalam melakukan aktivitas kehidupan sehari-hari, merasa terasing dan terisolir secara sosial sehingga menurunkan tingkat kemandirian dan kualitas hidup lansia tersebut (Manlea, 2016).

Menurut Diagnostic dan Statistic Manual of Mental Disorders (DSM-V), masalah kognitif dapat masuk salah satunya ke dalam kategori demensia.Demensia merupakan sindrom yang ditandai oleh berbagai gangguan fungsi kognitif antara lain intelegensi, belajar dan daya ingat, bahasa, pemecahan masalah, orientasi, persepsi, perhatian dan konsentrasi, penyesuaian dan kemampuan bersosialisasi (Nugroho, 2012).

Keluarga merupakan support system utama bagi lansia dalam mempertahankan kesehatannya. Peranan keluarga antara lain menjaga atau merawat lansia, mempertahankan dan meningkatkan status mental, mengantisipasi perubahan sosial ekonomi serta memberikan motivasi dan memfasilitasi kebutuhan spiritual bagi lansia. Lansia yang mengalami kemunduran fungsi kognitif atau demensia, memerlukan kesiapan keluarga untuk memenuhi kebutuhan sehari-hari lansia. Kesiapan adalah keseluruhan kondisi yang membuatnya siap untuk memberi respon atau jawaban di dalam cara tertentu terhadap suatu situasi. Kemampuan keluarga dalam memberikan asuhan kesehatan mempengaruhi status kesehatan keluarga. Kesanggupan keluarga melaksanakan pemeliharaan kesehatan dapat dilihat dari tugas kesehatan keluarga yang dilaksanakan. Keluarga yang dapat melaksanakan tugas kesehatan berarti sanggup menyelesaikan masalah kesehatan.

Posbindu (Pos Pembinaan Terpadu) adalah pos pelayanan kesehatan untuk masyarakat usia lanjut disuatu wilayah tertentu yang sudah disepakati, yang digerakkan oleh masyarakat dimana mereka bisa mendapatkan pelayanan kesehatan. Posbindu merupakan pengembangan 
dari kebijakan pemerintah melalui pelayanan kesehatan bagi lansia yang penyelenggaranya melalui program Puskesmas dengan melibatkan peran serta para lansia, keluarga, tokoh masyarakat dan organisasi sosial dalam penyelenggaraannya.

Program Posbindu meliputi pendataan sasaran setiap bulan sekali, pemeriksaan kesehatan (tekanan darah, timbang berat badan), bimbingan rohani, konseling, keterampilan, kesehatan jasmani, rekreasi, penyuluhan.

\section{METODE}

Penelitian dengan metode kuantitatif dengan desain penelitian cross-sectional digunakan untuk mengidentifikasi hubungan kesiapan keluarga dengan kondisi demensia lansia di Posbindu $\mathrm{X}$. Variabel Independen penelitian adalah kesiapan keluarga dan variabel dependen adalah kondisi demensia lansia. Populasi dan sampel adalah keluarga lansia yang terdaftar di Posbindu X berjumlah 96 keluarga dan 96 lansia.

Teknik pengumpulan sampel pada penelitian ini menggunakan non-probability sampling dengan jenis pengambilan sampel pada penelitian ini mengunakan total sampling (Sugiono, 2013). Kuesioner kesiapan keluarga menggunakan Skala Guttman yaitu : untuk pertanyaan positif $1=$ ya dan $0=$ tidak, untuk pertanyaan negatif $1=$ tidak dan $0=$ ya. Kondisi demensia lansia diukur menggunakan lembar observasi yang sudah baku yaitu Mini Mental State Examination (MMSE). Tiga kategori penelitian dipilah menggunakan MMSE yaitu: Nilai 27-30: Fungsi Kognitif Normal, Nilai 2126: Gangguan Kognitif Ringan, Nilai 11-20: Gangguan Kognitif Sedang, Nilai $<10$ : Gangguan Kognitif Berat. Kuesioner MMSE mengukur 11 komponen dari pemeriksaan kondisi mental lanjut lansia yaitu Orientasi (waktu dan tempat), Registrasi (nama tiga buah benda), atensi dan kalkulasi (hitungan), mengingat kembali (recall), bahasa (nama benda, ulang kalimat, lakukan perintah, baca dan laksanakan perintah, tulis kalimat dan buat gambar) (Aspiani, 2014; Azizah,2011).

Analisa data menggunakan analisis univariat dan uji chi square untuk melihat hubungan anta- antara kondisi demensia pada lansia dengan keluarga.

\section{HASIL}

Karakteristik responden yang terlibat dalam penelitian ini dikelompokkan berdasarkan karakteristik jenis kelamin, usia, dan pekerjaan sebagaimana dapat dilihat pada Tabel 1, 2, dan 3 .

Sementara itu, hasil pemeriksaan status demensia responden dapat dilihat pada Tabel 4, sedangkan data sebaran frekuensi kesiapan keluarga disajikan dalam Tabel 5.

Hasil penelitian sebagaimana tercantum pada Tabel 6 menunjukkan bahwa terdapat 66 responden yang memiliki kondisi demensia sedang, dimana $35(53,0 \%)$ responden memiliki kesiapan keluarga siap dan 31 (47,0\%) responden memiliki kesiapan keluarga tidak siap. Hasil uji Chi-Square diperoleh $p$-value $=0,896$, hal ini berarti bahwa Ha ditolak sehingga tidak ada hubungan kondisi demensia pada lansia dengan kesiapan keluarga.

\section{PEMBAHASAN}

\section{Kesiapan Keluarga}

Menurut Hersey dan Blanchard (dalam Judge\&Robbins, 2008) kesiapan (readiness) mengacu pada tingkat sampai mana seseorang memiliki kemampuan dan kesediaan untuk menyelesaikan tugas tertentu.Keluarga adalah dua orang atau lebih yang dibentuk berdasarkan ikatan perkawinan yang sah, mampu memenuhi kebutuhan hidup spiritual dan material yang layak, bertaqwa kepada Tuhan, memiliki hubungan yang selaras dan seimbang antara anggota keluarga dan masyarakat serta lingkungannya. Terdapat beberapa aspek yang membentuk kesiapan seseorang yaitu fisik (kondisi personal), psikososial (dukungan dan koping keluarga) dan kognitif (pengetahuan) (Argarini, 2011).

Hasil penelitian ini menunjukkan bahwa lebih dari setengah keluarga $(52,1 \%)$ memiliki kesiapan dan kurang dari setengahnya keluarga $(47,9 \%)$ memiliki ketidaksiapan. Menurut penelitian Suharni pada tahun 2010, setelah diri kita siap, kita perlu mulai melangkah ke lingkaran berikutnya, yaitu bagaimana kita memper- 
Tabel 1. Distribusi Frekuensi Karakteristik Lansia berdasarkan Jenis Kelamin di Posbindu X $(\mathbf{n}=96)$

\begin{tabular}{ccc}
\hline Jenis Kelamin & Frekuensi (responden) & Persentase (\%) \\
\hline Perempuan & 66 & 68,8 \\
Laki-Laki & 30 & 31,2 \\
\hline Jumlah Total & 96 & 100 \\
\hline
\end{tabular}

Tabel 2. Distribusi Frekuensi Karakteristik Lansia berdasarkan Usia menurut WHO di Posbindu X (n=96)

\begin{tabular}{ccc}
\hline Usia Menurut WHO & $\begin{array}{c}\text { Frekuensi } \\
\text { (responden) }\end{array}$ & Persentase (\%) \\
\hline 45-59tahun & 43 & 44,8 \\
$60-74$ tahun & 45 & 46,9 \\
$75-90$ tahun & 8 & 8,3 \\
\hline Jumlah Total & 96 & 100
\end{tabular}

Tabel 3. Distribusi Frekuensi Karakteristik Keluarga berdasarkan Pekerjaan Keluarga di Posbindu X (n=96)

\begin{tabular}{ccc}
\hline Pekerjaan & $\begin{array}{c}\text { Frekuensi } \\
\text { (responden) }\end{array}$ & Persentase (\%) \\
\hline Buruh & 9 & 9,4 \\
IRT (Ibu Rumah Tangga) & 55 & 57,3 \\
Swasta & 18 & 18,7 \\
Wirausaha & 7 & 7,3 \\
Pelajar & 6 & 6,3 \\
Guru & 1 & 1,0 \\
\hline Jumlah Total & 96 & 100 \\
\hline
\end{tabular}

Tabel 4. Distribusi Frekuensi Kondisi Demensia pada Lansia

\begin{tabular}{ccc}
\hline Kondisi Demensia pada Lansia & $\begin{array}{c}\text { Frekuensi } \\
\text { (responden) }\end{array}$ & Presentase (\%) \\
\hline Gangguan Kognitif Ringan & 19 & 19,7 \\
Gangguan Kognitif Sedang & 66 & 68,8 \\
Gangguan Kognitif Berat & 11 & 11,5 \\
\hline Jumlah Total & 96 & 100 \\
\hline
\end{tabular}

Tabel 5. Distribusi Frekuensi Kesiapan Keluarga di Posbindu X (n=96)

\begin{tabular}{ccc}
\hline Kesiapan Keluarga & Frekuensi responden) & Presentase (\%) \\
\hline Siap & 50 & 52,1 \\
Tidak Siap & 46 & 47,9 \\
\hline Jumlah Total & 96 & 100 \\
\hline
\end{tabular}


Tabel 6. Distribusi Frekuensi Hubungan Kondisi Demensia Lansia dengan Kesiapan Keluarga di Posbindu X

\begin{tabular}{|c|c|c|c|c|c|c|c|}
\hline \multirow{3}{*}{ Kondisi Demensia pada Lansia } & \multicolumn{4}{|c|}{ Kesiapan Keluarga } & \multirow{2}{*}{\multicolumn{2}{|c|}{ Total }} & \multirow{3}{*}{$\mathbf{P}_{\text {Value }}$} \\
\hline & \multicolumn{2}{|r|}{ Siap } & \multicolumn{2}{|c|}{ Tidak Siap } & & & \\
\hline & $\mathrm{n}$ & $\%$ & $\mathrm{n}$ & $\%$ & $\mathrm{n}$ & $\%$ & \\
\hline Gangguan Kognitif Ringan & 10 & $52,6 \%$ & 9 & $47,4 \%$ & 19 & $100 \%$ & \\
\hline Gangguan Kognitif Sedang & 35 & $53,0 \%$ & 31 & $47,0 \%$ & 66 & $100 \%$ & 0,877 \\
\hline Gangguan Kognitif Berat & 5 & $45,5 \%$ & 6 & $54,5 \%$ & 11 & $100 \%$ & \\
\hline Jumlah Total & 50 & & 46 & & 96 & & \\
\hline
\end{tabular}

lingkaran berikutnya, yaitu bagaimana kita mempersiapkan dukungan dari orang-orang di sekitar kita. Setelah memasuki usia tua kita juga tetap memerlukan dukungantersebut. Dukungan yang terutama dan terpenting tentunya datang dari keluarga dan temandekat. Tetaplah membina hubungan baik dengan keluarga dan teman. Mereka bisamenjadi sumber inspirasi dan sumber kekuatan mental serta emosi kita ketika memasuki masayang terindah dalam hidup kita tersebut.

Kesiapan keluarga dipengaruhi oleh beberapa faktor salah satunya ialah pekerjaan keluarga.Menurut Trisnawati (2002) dalam penelitian Suharni (2010), keadaan keuangan baik perorangan maupun kelompok lebih dikenal dengan sebutan status ekonomi, ternyata dari berbagai penelitian dampak status ekonomi terhadap pelayanan kesehatan lebih menonjol. Hal ini berdasarkan pemanfaatan pelayanan kesehatan adalah penghasilan keluarga, seperti ongkos berobat dan keikutsertaannya dalam asuransi kesehatan.Masyarakat dari sosial ekonomi rendah padaumumnya lebih sedikit mempunyai kesempatan menjangkau fasilitas pelayanan kesehatan.

Hal ini sesuai dengan teori yang kemukakan oleh Friedman (1998) dalam Rini (2010) bahwaposisi status ekonomi sangat mempengaruhi interpretasi individu tentang gejala penyakit.Umumnya, keluarga dengan status sosial ekonomi rendah menunggu hingga mereka tidak bisa apa-apa lagi sebelum mereka menyatakan diri mereka sakit. Mereka juga menganggap bah- bahwa kesehatan merupakan daftar kebutuhan paling bawah kecuali saat-saat krisis. Berdasarkan karakteristik pekerjaan keluarga di Posbindu $\mathrm{X}$ bahwa memiliki Buruh sebanyak 9 keluarga (9,4\%), IRT (Ibu Rumah Tangga) sebanyak 55 keluarga (57,3\%), Swasta sebanyak 18 keluarga $(18,8 \%)$, Wirausaha sebanyak 7 keluarga (7,3\%), Pelajar sebanyak 6 keluarga $(6,3 \%)$ dan Guru sebanyak 1 keluarga (1,0\%). Hal ini menunjukkan bahwa sebagian besar keluarga di Posbindu Xmempunyai pekerjaan sebagai Ibu Rumah Tangga (IRT), dan pekerjaan keluarga mempunyai pengaruh terhadap kesiapan keluarga dalam merawat anggota keluarganya.Hal ini dapat mempengaruhi banyaknya informasi yang didapatkan. Menurut Argarini (2011) kecocokan pekerjaan seseorang dan menimbulkan kepuasan dan keingintahuan terhadap sesuatu. Pekerjaan seseorang secara tidak langsung berhubungan dengan pengetahuan yang dimilikinya. Pengetahuan keluarga yang cukup perlu ditingkatkan karena hal ini akan menunjang kesiapan keluarga dalam memberikan perawatan.

Berdasarkan hasil penelitian yang dilakukan, kurang dari setengah keluarga yang ada di Posbindu RW 06 Cimareme berpendidikan SMA sebanyak 46 keluarga $(47,9 \%)$, berpendidikan SD sebanyak 20 keluarga (20,8\%), berpendidikan SMP sebanyak 26 keluarga $(27,1 \%)$, berpendidikan D3 sebanyak 3 keluarga $(3,1 \%)$ dan berpendidikan S1 sebanyak 1 keluarga $(1,0 \%)$. Sehingga dapat diketahui bahwa sebagian besar keluarga di Posbindu X pendidikannya yaitu SMA yang akan berpengaruh terhadap kesiapan 
keluarga. Pengetahuan yang dimiliki oleh seseorang salah satunya berasal dari pendidikan. Notoatmodjo (2007:139-141) mengemukakan bahwa aspek pengetahuan merupakan domain yang sangat penting untuk terbentuknya perilaku seseorang di mana semakin tinggi tingkat pengetahuan seseorang akan dapat mempengaruhi pola pikir dan sikap terhadap sesuatu hal ini akan mempengaruhi perubahan perilaku.

Ketika lansia melakukan kesalahan, hal yang harus dilakukan keluarga adalah tetap tenang, tidak menyalahkan, dan tidak beradu argumen mengenai hal yang benar atau yang salah (Jones,2012). Responden mengatakan bahwa mereka kesal ketika lansia melakukan kesalahan berulang-ulang terutama jika lansia lupa atau terjadi perubahan tingkah laku dan emosi yang susah dipahami. Menurut Lyketsos dan Rabins (2010) tingkah laku dan kondisi emosi individu dengan lansia seringkali merupakan bentuk komunikasi mengenai kebutuhannya yang belum terpenuhi karena kemampuan komunikasinya yang telah berkurang. Ketika keluarga dapat menjaga sikap tenang, keluarga dapat mendorong ketenangan pada lansia dan mencoba memvalidasi perasaan atau maksud yang ingin disampaikan oleh lansia.

\section{Kondisi Demensia pada Lansia}

Demensia merupakan sindrom yang ditandai oleh berbagai gangguan fungsi kognitif antara lain intelegensi, belajar dan daya ingat, bahasa, pemecahan masalah, orientasi, persepsi, perhatian dan konsentrasi, penyesuaian dan kemampuan bersosialisasi (Corwin, 2009). Hasil penelitian menunjukkan bahwa responden lansia $(19,7 \%)$ memiliki demensia ringan, lebih dari setengah responden lansia yaitu $(68,8 \%)$ memiliki demensia sedang, dan tidak seorangpun responden lansia yaitu $(11,5 \%)$ memiliki demensia berat. Seseorang yang sudah lanjut usia akan mengalami beberapa perubahan, tidak hanya perubahan fisik, psikologis, ataupun sosial tetapi juga mengalami perubahan kognitif yang menunjukkan kemunduran atau penurunan (Artinawati, 2014).

Penurunan fungsi kognitif ini dipengaruhi berbagai faktor, salah satunya adalah jenis ke- kelamin. Hasil penelitian yang dilakukan Hesti dkk (2008) dan Ramadian (2012) yang menunjukkan jumlah lansia perempuan lebih banyak mengalami gangguan kognitif dengan persentase $75 \%$ dan 93,4\%. Hasil penelitian Evenson (2015) menyatakan, bahwa penurunan kadar estrogen pada perempuan lanjut usia menyebabkan berkurangnya reseptor estrogen pada sistem limbik dan hipokampus, bagian dari otak yang berperan dalam proses kognitif dan memori, sehingga perempuan lanjut usia lebih beresiko mengalami penurunan kognitif. Hormon estrogen ini juga melindungi sel-sel otak dan partikelpartikel radikal bebas. Santoso dan Nur Rohmah (2009) mendukung pernyataan tersebut, dalam penelitiannya menyatakan bahwa permasalahan kesehatan lansia perempuan lebih kompleks daripada lansia laki-laki. Hal ini karena siklus hidup lansia perempuan yang mengalami menopause yang menyebabkan penurunan kadar estrogen yang membawa dampak negatif.

Usia yang semakin meningkat mengakibatkan perubahan anatomi dan biokimia susunan saraf pusat yang pada akhirnya dapat menyebabkan penurunan fungsi kognitif (Azizah, 2011). Otak dan serabut lansia mengalami atrofi yang progresif.Volume dan berat otak lansia berkurang berkaitan dengan berkurangnya kandungan protein dan lemak pada otak sehingga otak menjadi lebih ringan.Akson, dendrit dan badan sel mengalami banyak perubahan. Dendrit yang berfungsi sebagai sarana komunikasi antar sel saraf, daya hantar saraf pun mengalami penurunan sehingga proses informasi melambat, banyak informasi yang hilang selama transmisi, berkurangnya kemampuan mengakumulasi informasi dan mengambil informasi dan membuat keputusan yang berujung terjadinya penurunan fungsi kognitif lansia (Pudjiastuti, 2003 dan Setiadi $\mathrm{dkk}, 2009)$. Penurunan menyeluruh pada fungsi sistem saraf pusat ini dipercaya sebagai kontributor utama perubahan dalam kemampuan kognitif lansia dan efisiensi dalam pemrosesan informasi (Papalia, Olds \& Feldman, 2006). 


\section{Hubungan kesiapan keluarga dengan kondisi demensia lansia}

Demensia merupakan sindrom yang ditandai oleh berbagai gangguan fungsi kognitif antara lain intelegensi, belajar dan daya ingat, bahasa, pemecahan masalah, orientasi, persepsi, perhatian dan konsentrasi, penyesuaian dan kemampuan bersosialisasi. Kesiapan keluarga adalah persepsi keluarga tentang kesiapannya dilihat dari kondisi fisik dan psikologis serta pengetahuan yang dimiliki (Argarini, 2011)

Hasil penelitian menunjukkan bahwa dari 96 keluarga dan lansia yang menjadi responden penelitian, lebih dari setengahnya responden $(53,0 \%)$ atau sebanyak 35 responden memiliki kondisi demensia yang sedang dengan kesiapan keluarga yang siap dan lebih dari setengahnya $(54,5 \%)$ atau sebanyak 6 responden memiliki kondisi demensia yang berat dengan ketidaksiapan keluarga dengan kondisi demensia pada lansia. Hasil penelitian melalui analisa dengan uji chi-square diperoleh P-value 0,896 sehingga dapat disimpulkan bahwa tidak ada hubungan antara kesiapan keluarga dengan kondisi demensia pada lansia di Posbindu RW 06 Cimareme.

Dengan kondisi lansia yang demensia ringan terdapat 10 keluarga yang siap dan dengan kondisi lansia yang demensia sedang juga terdapat 35 keluarga siap. Hal ini dapat dilihat dari kuesioner bahwa keluarga lebih siap mendampingi lansia dalam bersosialisasi dengan orang lain, bersedia untuk rutin memeriksa kesehatan lansia, siap bertanya ke pihak posbin$\mathrm{du}$ terdekat tentang cara merawat lansia, dan bersedia memberikan suasana yang nyaman di rumah untuk lansia. Berbeda halnya dengan kondisi demensia berat pada lansia terdapat 6 keluarga tidak siap. Hal ini dapat dilihat dari kuesioner, keluarga emosi ketika lansia sulit dalam memahami atau mengerti perkataan orang lain juga merasa terbebani dalam merawat lansia demensia. Seharusnya keluarga memahami tugas kesehatan dan merawat lansia.Ini sesuai dengan teori Friedman (2010) dalam Aspiani (2014) mengenai tugas kesehatan keluarga. Beberapa teori perubahan perilaku kesehatan menunjukkan bahwa keluarga adalah pengaruh utama, baik pada status kesehatan maupun pada perilaku kesehatan anggota keluarga.

Keluarga yang merawat lansia demensia memerlukan pemahamanawal tentang kondisi demensiadengan respon yang tepat. Keluarga memegang peranan penting dalam konsep sehat sakit anggota keluarganya yang sakit. Individu yang mempunyai dukungan keluarga yang kuat lebih cenderung untuk mengadopsi dan mempertahankan perilaku kesehatan yang baru daripada individu yang tidak memiliki dukungan keluarga untuk mengubah perilaku kesehatannya (Friedman, Bowden \& Jones, 2003), disamping itu dukungan keluarga yang tinggi ternyata menunjukkan penyesuaian yang lebih baik terhadap kondisi kesehatan anggota keluarganya. Memeriksakan kesehatan secara teratur dan pemeliharaan kesehatan lansia adalah tanggung jawab bersama.

Keluarga mempunyai peran penting dalam kehidupan lansia. Ketika lansia membutuhkan bantuan, maka keluarga yang akan memberikan bantuan tersebut. Khususnya ketika adanya perubahan yang terjadi pada lansia yaitu perubahan fungsi fisik dan mental.Keberadaan lansia dalam keluarga dapat mempengaruhi fungsi keluarga yang selanjutnya turut menentukan kemampuan keluarga untuk mendukung pencapaian kualitas hidup lansia semaksimal mungkin.

Perubahan tanggung jawab keluarga mengurus lansia disebabkan keluarga yang sangat sibuk dengan pekerjaannya sehingga tidak mempunyai waktu mengurus lansia atau bahkan ditinggal sendiri oleh keluarga yang membuat hidup lansia tidak potensial dan menjadi telantar. Kondisi ini yang menyebabkan keluarga memilih pelayanan institusi untuk mengurus lansia.Salah satu dari pelayanan institusi lansia adalah panti sosial. Penelitian Wiyono, dkk. dalam penelitian yang berjudul pengalaman keluarga merawat lansia dengan tingkat ketergantungan tinggi di rumah mendapat hasil bahwa alasan utama merawat lansia karena kewajiban keluarga terhadap lansia yang terdiri dari tanggung jawab moral keluarga. Azizah (2011) keluarga terdiri dari anggota yang saling ketergantungan satu sama lainnya dan berpengaruh dengan yang lainnya. Keluarga bisa menjadi motivator kuat 
bagi lansia apabila selalu menyediakan diri untuk mendampingi dan mengantar lansia ke pelayanan kesehatan. Hal ini dikarenakan didalam proses pembentukan dan perubahan, perilaku dipengaruhi oleh beberapa faktor yang berasal dari dalam dan dari luar individu itu sendiri.

Sebagai besar keluarga tidak mencari informasi karena menganggap demensia sebagai kondisi yang normal karena proses penuaan dan meskipun kondisi perburukan yang terjadi mereka tidak mencari pelayanan kesehatan.

Oleh karena itu, perawatan yang mereka berikan pun sesuai dengan apa yang mereka tahu meskipun terkadang mereka juga kebingungan untuk menghadapi sikap dan perilaku lansia (Rahmawati, 2013).

\section{DAFTAR PUSTAKA}

Argarini, Diah. (2011). Pengaruh Perencanaan Pemulangan (Discharge Planning) Terhadap Kesiapan Keluarga Pasien Menghadapi Pemulangan pada Pasien Stroke di RSD di Soeban di Jember.

Artinawati, Sri. (2014). A suhan Keperawatan Gerontik. Bogor : In Media.

Aspiani, Reny Yuli. 2014. Buku Ajar Asuhan Keperawatan Gerontik. Jakarta: CV.Trans Info Media.

Azizah, Lilik Ma'fifatul. 2011. Keperawatan Lanjut Usia. Yogyakarta: GrahaIlmu.

Badan Pusat Statistik. (2010). Statistik Penduduk Lanjut Usia. Jakarta: Salemba Medika

Chaplin, J.P. (2006). Kamus lengkap Psikologi. (Penerj. Kartini Kartono). Jakarta : PT Raja Grafindo Persada.

Data Badan Pusat Statistik Jawa Barat. 2013. 5 April 2017. http://jabar.bps.go.id/ linkTabelStatis/viiew/id/75.

Data Dinas Kesehatan Jawa Barat. 2014. Profil Kesehatan Tahun 2014. 5 April 2017. http:// www.diskes.jabarprov.go.id

Friedman, Family Nursing: Research, Theory, and Practice, 5th Edition. The University of Arizona
Hal ini sesuai dengan penelitian Zwanswijk (2013) yang menyatakan bahwa 75\% caregiver yang merawat lansia dengan demensia mengalami masalah untuk menangani perubahan yang terjadi pada lansia karena kurangnya pengetahuan mengenai demensia atau pun cara merawatnya.

\section{SIMPULAN}

Lebih dari setengahnya responden $(68,8 \%)$ memiliki gangguan kognitif sedang. Lebih dari setengahnya responden $(52,1 \%)$ dengan kesiapan keluarga di Posbindu RW 06 Cimareme. Tidak ada hubungan hubungan kesiapan keluarga dengan kondisi demensia lansiadi Posbindu Wilayah Kerja Puskesmas Cimareme.

Manlea, Edita MB. (2016). Hubungan Karakteristik Lansia dengan Pemenuhan Aktivitas Sehari-hari Lansia di Posbindu Desa Kertamulya Wilayah Kerja Puskesmas $\mathrm{Pa}$ dalarang.

Maryam, dkk (2012) Hubungan Tingkat Pendidikan Dan Activity Daily Living Dengan Demensia Pada Lanjut Usia Di Panti Werdha.

Mujahidullah. (2012) Keperawatan Geriatrik: Merawat Lansia Dengan Cinta dan Kasih Sayang. Penerbit : Pustaka Jaya. Jogjakarta.

Notoatmodjo, Soekidjo. (2010). Metodologi Penelitian Kesehatan. Jakarta: Rineka Cipta.

Rakhmawati. Vera. (2012). Dukungan keluarga pada lansia yang mengalami demensia. http://lib.ui.ac.id/naskahringkas/2015-08/ S46565-vera\%20rakhmawati\%20nugraheni

Ramadian. (2012). Gambaran Fungsi Kognitif Pada Lansia Di Tiga Yayasan Manula Di Kecamatan Kawangkoan.

Rini Suharni (2010). Tingkat pengetahuan keluarga dalam merawat lansia dan Kesiapan Keluarga Dalam Merawat Anggota Keluarga Yang Menderita Stroke Di Desa Kebak kramat Karanganyar. 
Robbins, Stephen P. \& Timothy A. Judge. (2008). Perilaku Organisasi Edisi ke-12, Jakarta: Salemba Empat. http:// www.sciepub.com/reference/151297

Setiati.(2013). Konsep dan Praktik Penulisan riset Keperawatan. Edisi kedua. Yogyakarta: Graha Ilmu.

Sunaryo, dkk. (2016). Asuhan Keperawatan Gerontik. Yogyakarta : Andi.
Wiyono, Joko dkk. Pengalaman Keluarga Merawat Lansia dengan Tingkat Ketergantungan Tinggi di Rumah, Kota Malang, Jawa Timur: Studi Fenomenologi.

Zwanswijk (2013). Informal Caregiver Of People With Dementia : Problems, Needs, And Support In The Initial Stage And In Subsequent Stage Of Dementia: A Quetionnaire Survey. The Open Nursing Journal. Vol.7, p. 6-13. 